\title{
PERAN SUMBER DAYA MANUSIA DALAM PENGEMBANGAN PARIWISATA BUDAYA DI KABUPATEN CIAMIS
}

\author{
Sri Pajriah ${ }^{1}$ \\ Dosen Pendidikan Sejarah Universitas Galuh Ciamis \\ Jl. R. E. Martadinata No. 150 Ciamis, 46274 Jawa Barat
}

\begin{abstract}
ABSTRAK
Penelitian ini bertujuan untuk menganalisis peran sumber daya manusia dalam pengembangan pariwisata budaya di Kabupaten Ciamis. Adapun metode yang digunakan dalam penelitian ini adalah metode penelitian sejarah dalam upaya untuk mendapatkan data dan fakta yang ada di lapangan. Berdasarkan hasil penelitian ini bahwa peran sumber daya manusia sebagai faktor kunci keberhasilan dalam mewujudkan pengembangan pariwisata budaya di Kabupaten Ciamis. Peran SDM sebagai motor penggerak industri pariwisata, pencipta produk industri pariwisata, dan sebagai penentu daya saing industri pariwisata. Hal ini dapat diwujudkan melalui pendidikan pariwisata dan pelatihan pemandu wisata yang harus dimiliki bagi masyarakat khususnya berada di daerah wisata untuk mengembangkan pariwisata budaya di wilayah Kabupaten Ciamis, karena melalui kegiatan tersebut akan lebih meningkatkan mutu, kinerja dan hasil yang diperoleh menjadi lebih baik. Maka, peran SDM sangat menunjang keberhasilan bagi pengembangan pariwisata budaya di Kabupaten Ciamis dengan kompetensi yang dimilikinya, sehingga objek wisata budaya yang ada di Kabupaten Ciamis menjadi tujuan wisata yang lebih menarik dan memiliki keunikan yang kaya akan nilai sejarah dan budaya Galuh serta bermanfaat bagi masyarakat yang berada di daerah wisata sebagai sarana memperoleh penghasilan sehingga kesejahteraan masyarakatpun akan lebih meningkat.
\end{abstract}

\section{Kata Kunci: Sumber Daya Manusia, pengembangan dan pariwisata budaya}

\begin{abstract}
This study aims to analyze the role of human resources in the development of cultural tourism in Ciamis Regency. The method used in this study is a historical research method in an effort to obtain data and facts in the field. Based on the results of this study, the role of human resources as a key success factor in realizing the development of cultural tourism in Ciamis Regency. The role of Human Resources as the driving force of the tourism industry, the creator of tourism industry products, and as a determinant of the competitiveness of the tourism industry. This can be realized through tourism education and must-have tour guide training for the community, especially in tourist areas to develop cultural tourism in the Ciamis Regency area, because through these activities the quality, performance and results obtained will be better. So, the role of Human Resources greatly supports the success of the development of cultural tourism in Ciamis Regency with its competencies, so that cultural tourism objects in Ciamis Regency become more attractive and unique tourist destinations that are rich in Galuh's historical and cultural values and beneficial for communities in tourist areas as a means of earning income so that the welfare of the community will increase.
\end{abstract}

\section{Keywords: Human Resources, development and cultural tourism}

\section{PENDAHULUAN}

John Naisbitt dalam bukunya Global Paradox, pariwisata dapat dikategorikan sebagai industri terbesar dunia (the world's largest industry) dijelaskan bahwa sekitar 8 persen dari

\footnotetext{
${ }^{1}$ Penulis Koresponden

E-mail address: sripajriahunigal@gmail.com doi: http://dx.doi.org/10.25157/ja.v5i1.1913
}

ekspor barang dan jasa, pada umumnya, berasal dari pariwisata. Di Asia Tenggara, berdasarkan catatan WTO, pariwisata menyumbang devisa Negara sebesar 10-12 persen dari DGP dan 7-8 persen dari total employment (Etyanto dalam Muallidin, 2007:1). Indonesia sendiri, sebagai 
Negara urutan kedelapan, dikunjungi 5,064 juta orang dengan perolehan devisa 5,7 miliar dolar Amerika pada tahun 2000 (Muallidin, 2007: 5).

Pariwisata di Indonesia merupakan salah satu sektor ekonomi penting. Di samping sebagai mesin penggerak ekonomi, pariwisata adalah wahana yang menarik untuk mengurangi angka pengangguran karena pengembangan pariwisata secara menyeluruh diharapkan akan dapat menciptakan lapangan pekerjaan yang cukup besar di daerah-daerah yang menjadi destinasi wisata. Pariwisata merupakan sektor yang terus menerus dikembangkan pemerintah sebagai pilar pembangunan nasional karena mampu menopang perekonomian nasional pada saat dunia sedang mengalami krisis. Undang-Undang Nomor 10 Tahun 2009 tentang kepariwisataan menyatakan bahwa pembangunan kepariwisataan diperlukan untuk mendorong pemerataan kesempatan berusaha dan memperoleh manfaat serta mampu menghadapi tantangan perubahan kehidupan lokal, nasional, dan global (Ethika, 2016: 134).

Salah satu daerah yang memiliki potensi pariwisata menarik adalah Kabupaten Ciamis, Provinsi Jawa Barat. Kabupaten Ciamis berdasarkan letak geografisnya berada pada posisi yang strategis dilalui jalan nasional lintas Jawa Barat-Jawa Tengah serta jalan provinsi lintas Ciamis-Cirebon-Jawa Tengah. Kabupaten Ciamis itu sendiri, memiliki potensi pariwisata dengan daya tarik wisata alam dan wisata budaya yang cukup potensial untuk dikembangkan. Dalam tulisan ini fokus kajian pada potensi pariwisata budaya. Adapun, potensi pariwisata budaya yang dimiliki Kabupaten Ciamis antara lain: Cagar Budaya Karangkamulyan, Situs Astana Gede Kawali, Situs Gunung Susuru, Situs Tambaksari, Kampung Kuta, Situ Lengkong, upacara adat Nyangku, upacara adat Ngikis, upacara adat Misalin, upacara adat Nyuguh, upacara adat Merlawu, serta kesenian daerah Bebegig, Wayang Landung, Gembyung Buhun, Tari Kele, Debus Panjalu, Karinding (Dinas Pariwisata \& Ekonomi Kreatif, 2016: 1). Destinasi pariwisata budaya tersebut diharapkan menjadi daerah wisata andalan Kabupaten Ciamis setelah Pangandaran menjadi kabupaten baru (BPS Kab. Ciamis, 2014: 1).

Sunaryo dalam Khotimah dkk (2017: 57), menjelaskan bahwa pariwisata budaya adalah jenis obyek daya tarik wisata (ODTW) yang berbasis pada hasil karya cipta manusia baik yang berupa peninggalan budaya maupun nilai budaya yang masih hidup sampai sekarang.
Senada diungkapkan Ismayanti dalam Larasati dan Rahmawati (2017, C530) menjelaskan bahwa pariwisata budaya adalah jenis pariwisata budaya berupa gagasan, aktifitas, dan artefak sebagai potensi daya tarik.

Berdasarkan program dan kegiatan pada urusan pariwisata yang dilaksanakan oleh Dinas Pariwisata dan Ekonomi Kreatif Kabupaten Ciamis pada Tahun 2014 terdapat tiga program dan lima belas kegiatan. Adapun ketiga program tersebut adalah: (1) Program pengembangan pemasaran pariwisata (2) Program pengembangan destinasi pariwisata (3) Program pengembangan kemitraan. Ketiga program tersebut telah terealisasikan, namun apabila hasil evaluasi berdasarkan capaian kinerja atas kunjungan wisata dari target pada tahun 2014 sebanyak 500.000 orang dapat terealisasikan sebanyak 291.293 orang dengan tingkat capaian sebesar 58,38 \%. Sementara, kontribusi sektor pariwisata terhadap Produk Domestik Regional Bruto Atas Dasar Harga Berlaku (PDRB AdHB) dari target pada Tahun 2014 sebesar 18\% dapat terealisasi sebesar 4,83\% dengan tingkat capaian sebesar 26,83\%. Sehingga kunjungan wisatawan pada destinasi pariwisata di wilayah Kabupaten Ciamis belum optimal (LKPB Ciamis, 2015: IV170-IV173). Hal ini dikarenakan para pekerja wisata belum optimal dalam mendukung pariwisata yang berada di kawasan destinasi pariwisata Kabupaten Ciamis. Selain itu, para pekerja wisata belum memiliki pengetahuan dan pemahaman tentang potensi wisata yang berada di wilayahnya dalam menopang penghasilan untuk meningkatkan kesejahteraan masyarakat.

Keberadaan sumber daya manusia (SDM) berperanan penting dalam pengembangan pariwisata. SDM pariwisata mencakup wisatawan/pelaku wisata (tourist) atau sebagai pekerja (employment). Peran SDM sebagai pekerja dapat berupa SDM di lembaga pemerintah, SDM yang bertindak sebagai pengusaha (wirausaha) yang berperan dalam menentukan kepuasan dan kualitas para pekerja, para pakar dan profesional yang turut berperan dalam mengamati, mengendalikan dan meningkatkan kualitas kepariwisataan serta yang tidak kalah pentingnya masyarakat di sekitar kawasan wisata yang bukan termasuk ke dalam kategori di atas, namun turut menentukan kenyamanan, kepuasan para wisatawan yang berkunjung ke kawasan tersebut.

Pariwisata sebagai sebuah industri yang sangat bergantung pada keberadaan manusia. Terwujudnya pariwisata merupakan interaksi 
dari manusia yang melakukan wisata yang berperan sebagai konsumen yaitu pihak-pihak yang melakukan perjalanan wisata/wisatawan dan manusia sebagai produsen yaitu pihak-pihak yang menawarkan produk dan jasa wisata. Sehingga aspek manusia salah satunya berperan sebagai motor penggerak bagi kelangsungan industri pariwisata di suatu negara (Setiawan, 2016: 24).

SDM merupakan salah satu faktor yang berperan penting dalam memajukan sektor pariwisata. Pentingnya SDM di sektor pariwisata adalah manusia (people) merupakan sumber daya yang sangat penting di sebagian besar organisasi. Khususnya di organisasi berbasis jasa (service-based organization), SDM berperan sebagai faktor kunci dalam mewujudkan keberhasilan kinerja (Evans, Campbell, \& Stonehouse, 2003). Pada beberapa industri, faktor manusia berperan penting dan menjadi faktor kunci sukses terhadap pencapaian kinerja. Seperti pada industri pariwisata, dimana perusahaan memiliki hubungan langsung yang bersifat intangible (tak berwujud) dengan konsumen yang sangat bergantung pada kemampuan individu karyawan dalam membangkitkan minat dan menciptakan kesenangan serta kenyaman kepada para konsumennya (Setiawan, 2016: 23-24).

Produk industri pariwisata adalah jasa, oleh karena itu penekanannya harus pada segi pelayanan yang disesuaikan dengan kebutuhan wisatawan. Dalam industri pariwisata, kualitas pelayanan merupakan indikator utama yang menunjukkan tingkat professionalnya (Nandi, 2008: 5). Pengembangan SDM di industri pariwisata saat ini menghadapi tantangan global yang memerlukan solusi dengan menembus batasan-batasan negara, wilayah dan benua. Salah satu solusi yang perlu ditempuh adalah dengan meningkatkan kompetensi SDM yang dimiliki suatu Negara termasuk Indonesia melalui peningkatan kualitas pendidikan dan pelatihan yang tepat.

Dari uraian di atas maka peran SDM dalam pengembangan pariwisata budaya di Kabupaten Ciamis sangat penting dikarenakan SDM tersebut merupakan sebagai motor penggerak industri pariwisata, peran SDM sebagai pencipta produk industri pariwisata, dan sebagai penentu daya saing industri pariwisata. Maka atas dasar pemikiran tersebut, penulis akan meneliti "Peran Sumber Daya Manusia Dalam Pengembangan Pariwisata Budaya di Kabupaten Ciamis".
Sesuai dengan fokus penelitian di atas, rumusan masalah yang dijadikan pertanyaan pokok dalam penelitian ini ialah: Bagaimana peran sumber daya manusia dalam pengembangan pariwisata budaya di Kabupaten Ciamis?

Hasil penelitian ini diharapkan berguna baik secara teoritis maupun praktis. Manfaat secara teoritis adalah pengembangan ilmu yang relevan dengan masalah penelitian. Secara khusus penelitian ini sangat berguna bagi beberapa pihak antara lain: 1) Bagi pemerintah, dapat memberikan kontribusinya dalam peningkatan pemasukan atau pendapatan asli daerah, membuka lahan kerja baru dan membantu dalam usaha pengentasan kemiskinan di wilayah. 2) Bagi pendidik, destinasi pariwisata budaya sebagi media pembelajaran sejarah melalui kunjungan peserta didik ke objek wisata budaya yang ada di Kabupaten Ciamis. 3) Bagi siswa, menumbuhkan apresiasi dan cinta terhadap peninggalan sejarah dan budaya yang ada dilingkungannya sebagai potensi pariwisata budaya yang memiliki nilai sejarah dan budaya yang tinggi untuk dijaga dan dilestarikan. 4) Bagi masyarakat, proses pembelajaran bagi masyarakat dalam melestarikan konservasi cagar budaya yang ada di Kabupaten Ciamis.

\section{METODE PENELITIAN}

Penelitian ini menggunakan metode penelitian sejarah dalam upaya untuk mendapatkan data dan fakta yang ada dilapangan. Langkah pertama pada metode sejarah adalah heuristik atau pengumpulan sumber. Dalam penelitian ini data yang dibutuhkan berupa pengembangan pariwisata budaya di Kabupaten Ciamis. Mengenai pengembangan ini terkait dengan upaya untuk meningkatkan kemampuan intelektual agar melaksanakan pekerjaan kearah yang lebih baik. Peran Sumber Daya Manusia dalam pengembangan pariwisata budaya di Kabupaten Ciamis dapat dilakukan melalui kegiatan pendidikan dan pelatihan.

Tahap kedua adalah melakukan kritik sumber, baik secara eksternal maupun internal. Kritik eksternal digunakan untuk menilai otentisitas sumber, sedangkan kritik internal digunakan untuk menilai kredibilitas sumber. Selanjutnya, melakukan proses verifikasi bahan dokumen disebut juga kolasi, yaitu membandingkan antara beberapa dokumen 
sehingga terlihat adanya kesesuaian maupun kontradiksi antar fakta. Maka, diperolehlah fakta sejarah yang dapat dipertanggungjawabkan.

Tahap ketiga adalah melakukan interpretasi. Fakta sejarah yang dihasilkan dari proses kritik sumber sejarah bersifat tunggal. Untuk mengaitkan antar sumber dilakukan proses penafsiran atau interpretasi dan penjelasan hubungan antar fakta (eksplanasi).

Tahap keempat adalah historiografi. Tahap ini merupakan tahap penulisan sejarah berbasis fakta-fakta sejarah yang telah mengalami proses interpretasi dan eksplanasi (Wasino, 2016: 63-64).

\section{HASIL PENELITIAN DAN PEMBAHASAN}

Geografis wilayah Kabupaten Ciamis berada pada $108^{\circ} 19^{\prime}$ sampai dengan $108^{\circ} 42^{\prime}$ Bujur Timur dan $7^{\circ} 40^{\prime} 20^{\prime}$ " sampai dengan 7041'20' Lintang Selatan. Kecamatan paling Utara adalah Kecamatan Sukamantri berada pada titik 7,082 garis Lintang Selatan, Kecamatan paling Barat adalah Kecamatan Cihaurbeuti dengan titik 108,202 Bujur Timur, Kecamatan paling Selatan adalah Kecamatan Pamarican berada pada titik 7,461 Lintang Selatan dan Kecamatan paling Timur adalah Kecamatan Lakbok dengan titik 108,682 Bujur Timur. Wilayah sebelah Utara berbatasan dengan Kabupaten Majalengka dan Kabupaten Kuningan, sebelah Barat dengan Kabupaten Tasikmalaya dan Kota Tasikmalaya, sebelah Timur dengan Kota Banjar dan Propinsi Jawa Tengah, dan sebelah Selatan dengan Kabupaten Pangandaran. Luas Wilayah Kabupaten Ciamis secara keseluruhan mencapai 143,387 ha.

Kabupaten Ciamis cukup potensial untuk pertanian dan pariwisata karena merupakan jalur tranportasi antar kota maupun antar propinsi yang melewati pusat kota. Jalur lalu lintas antar propinsi melewati kecamatan Cihaurbeuti, Sindangkasih, Cikoneng, Ciamis, Cijeungjing dan Cisaga. Kabupaten Ciamis juga memiliki beberapa tempat pariwisata yang merupakan peninggalan tataran kerajaan Galuh dan wisata alam, diantaranya Astana Gede, Situs Ciungwanara dan Situ Lengkong yang diharapkan menjadi daerah wisata andalan Kabupaten Ciamis setelah Pangandaran menjadi Kabupaten baru (BPS, 2014: 3).

Berdasarkan salah satu misi pembangunan Kabupaten Ciamis 2014-2019 adalah "Meningkatkan Kualitas Sumber Daya Manusia; pembangunan yang menekankan pada kualitas Sumber Daya Manusia (SDM) ini ditandai dengan membaiknya taraf pendidikan dan derajat kesehatan penduduk, yang didukung oleh meningkatnya ketersediaan dan kualitas pelayanan sosial dasar bagi masyarakat agar lebih produktif serta berdaya saing untuk mencapai kehidupan yang lebih makmur dan sejahtera". Dalam hal ini, pembangunan yang menekankan pada kualitas SDM pada bidang pariwisata, kebudayaan, pemuda dan olahraga, kesehatan dan pendidikan (RJPMD Kab. Ciamis, 2014: 3, 20). Namun, dalam tulisan ini fokus pada peran SDM dalam pengembangan pariwisata budaya di Kabupaten Ciamis. Sebagaimana diketahui bahwa Kabupaten Ciamis memiliki sejarah daerahnya tersendiri yaitu sebelum terbentuk menjadi sebuah Kabupaten Ciamis, pada waktu itu merupakan sebagai sebuah Kerajaan Galuh. Pada tahun 670 M, Tarumanagara sebuah kerajaan besar di Jawa Barat telah berakhir, sekaligus mengakhiri Dinasti Warman. Sebagai penerusnya, muncul dua kerajaan baru di bumi Jawa Barat yaitu 1) di sebelah barat Citarum menjadi Kerajaan Sunda; dan 2) di sebelah timurnya menjadi Kerajaan Galuh (Iskandar, 2001: 110).

Awal mula sebagai sebuah Kerajaan Galuh menjadi Kabupaten Imbanagara, Kabupaten Galuh dan menjadi Kabupaten Ciamis, tentunya memiliki perjalanan sejarah yang panjang, adanya peninggalan-peninggalan sejarah dan budaya sebagai hasil dari ide, gagasan, perilaku dan karya masyarakat pada zamannya. Dengan demikian, masyarakat Kabupaten Ciamis memiliki nilai sejarah dan budaya yang tinggi untuk tetap dilestarikan dan diwariskan kepada generasi penerus. Potensi nilai sejarah dan budaya yang dimiliki masyarakat Kabupaten Ciamis dapat menjadi sebuah wisata budaya bagi wisatawan domestik maupun mancanegara yang ingin mengetahui secara detail mengenai sejarah dan budaya yang ada di Kabupaten Ciamis. Adapun, potensi pariwisata budaya yang dimiliki Kabupaten Ciamis antara lain: Cagar Budaya Karangkamulyan, Situs Astana Gede Kawali, Situs Gunung Susuru, Situs Tambaksari, Kampung Kuta, Situ Lengkong, upacara adat Nyangku, upacara adat Ngikis, upacara adat Misalin, upacara adat Nyuguh, upacara adat Merlawu, serta kesenian daerah Bebegig, Wayang Landung, Gembyung Buhun, Tari Kele, Debus Panjalu, Karinding (Dinas Pariwisata \& Ekonomi Kreatif, 2016: 1). Destinasi pariwisata 
budaya tersebut diharapkan menjadi daerah wisata andalan Kabupaten Ciamis setelah Pangandaran menjadi kabupaten baru (BPS Kab. Ciamis, 2014: 1).

Ethika (2016: 140-141), menjelaskan bahwa wisata berbasis budaya adalah salah satu jenis kegiatan pariwisata yang menggunakan kebudayaan sebagai objeknya. Pariwisata jenis ini dibedakan dari minat-minat khusus lain, seperti wisata alam, dan wisata petualangan. Ada 12 unsur kebudayaan yang dapat menarik kedatangan wisatawan yaitu: a. Bahasa (language); b. Masyarakat (traditions); c. Kerajinan tangan (handicraft); d. Makanan dan kebiasaan makan (foods and eating habits); e. Musik dan kesenian (art and music); f. Sejarah suatu tempat (history of the region); Cara Kerja dan Teknolgi (work and technology); h. Agama (religion) yang dinyatakan dalam cerita atau sesuatu yang dapat disaksikan; i. Bentuk dan karakteristik arsitektur di masing-masing daerah tujuan wisata (architectural characteristicin the area); j. Tata cara berpakaian penduduk setempat (dress and clothes); k. Sistem pendidikan (educational system); 1. Aktivitas pada waktu senggang (leisure activities).

Pariwisata budaya sebagai salah satu produk pariwisata merupakan jenis pariwisata yang disebabkan adanya daya tarik dari seni budaya suatu daerah. Pariwisata budaya pada intinya merupakan jenis pariwisata yang menawarkan kebudayaan yang berupa atraksi budaya baik yang bersifat tangibel atau konkret maupun intangibel atau abstrak, juga yang bersifat living culture (budaya yang masih berlanjut) dan cultural heritage (warisan budaya masa lalu), sebagai daya tarik utama untuk menarik kunjungan wisatawan.

\section{Peran Sumber Daya Manusia Dalam Pengembangan Pariwisata Budaya Di Kabupaten Ciamis}

Pariwisata sebagai sebuah industri yang sangat bergantung pada keberadaan manusia. Terwujudnya pariwisata merupakan interaksi dari manusia yang melakukan wisata yang berperan sebagai konsumen yaitu pihak-pihak yang melakukan perjalanan wisata/wisatawan dan manusia sebagai produsen yaitu pihak-pihak yang menawarkan produk dan jasa wisata. Sehingga aspek manusia salah satunya berperan sebagai motor penggerak bagi kelangsungan industri pariwisata di suatu negara (Setiawan, 2016: 24).
Dalam suatu organisasi hal yang paling penting yang perlu diperhatikan adalah sumber daya manuisa yang menjadi pendukung utama tercapai tujuan organisasi. Sumber daya manusia menempati posisi strategis dalam suatu organisasi, maka dari itu sumber daya manusia harus digerakkan secara efektif dan efisien sehingga mempunyai tingkat hasil daya guna yang tinggi. Manajemen SDM adalah rangkaian strategis, proses dan aktivitas yang didesain untuk menunjang tujuan perusahaan dengan cara mengintegrasikan kebutuhan perusahaan dan individunya (Rivai \& Sagala, 2009:1).

Dalam hal ini menurut Tjokrowinoto dkk dalam Nandi (2008: 4), bahwa figur atau sosok sumber daya manusia pada abad 21 adalah manusia-manusia yang memiliki kualifikasi sebagai berikut : 1. Memiliki wawasan pengetahuan (knowledge), ketrampilan (skill), dan sikap atau perilaku (attitude) yang relevan dan mampu menunjang pencapaian sasaran dan bidang tugas dalam suatu organisasi. 2. Memiliki disiplin kerja, dedikasi dan loyalitas yang tinggi terhadap pekerjaan dan terhadap organisasi. 3 . Memilki rasa tanggungjawab dan pengertian atau pemahaman yang mendalam terhadap tugas dan kewajibanya sebagai karyawan atau unsure manajemen organisasi. 4. Memiliki jiwa kemauan yang kuat untuk berprestasi produktif dan bersikap professional. 5. Memilki kemauan dan kemampuan untuk selalu mengembangkan potensi dan kemampuan diri pribadi demi kelancaran pelaksanaan tugas organisasi. 6 . Memiliki kemampuan yang tinggi dalam bidang tehnik maupun manajemen dan kepemimpinan. 7. Memiliki keahlian dan ketrampilan yang tertinggi dalam bidang tugas dan memiliki kemampuan alih teknologi. 8. Memiliki jiwa kewirausahaan (enterpreneurship) yang tinggi dan konsisten 9. Memilki pola pikir dan pola tindak yang sesuai dengan visi, misi, dan budaya kerja organisasi.

Sumber daya manusia (SDM) pariwisata merupakan individu/pelaku industri pariwisata yang secara langsung ataupun tidak langsung memiliki interaksi/keterkaitan dengan seluruh komponen periwisata. SDM pariwisata memegang peranan penting dalam menggerakkan roda industri ini. Dengan memiliki SDM pariwisata yang memiliki kompetensi yang baik, maka pembangunan pariwisata dapat dilakukan secara optimal (https://ejournal.unisba.ac.id/index.php/perform a/article/download/3040/1901). 
Menurut Schuler dan Youngblood dalam Krisdianto dan Nurhajati (2017: 85-86), menekankan bahwa mempelajari pengembangan sumber daya manusia dari organisasi, manusia sebagai bagian dari organisasi, sehingga diungkapkan bahwa pengembangan sumber daya manusia pada suatu organisasi akan melibatkan berbagai faktor yaitu pendidikan dan pelatihan. Pelatihan membantu pegawai untuk memahami suatu pengetahuan praktis dan penerapannya. Pada pengembangan kualitas manusia melalui pengembangan kemampuan berfikir yang antara lain dilaksanakan melalui peningkatan kemampuan untuk menilai keadaan. Tak dapat dipungkiri, pendidikan dan pelatihan merupakan salah satu pendekatan utama dalam mengembangkan sumber daya manusia. Hal ini dilakukan sebagai pendekatan, karena pendidikan dan pelatihan mempunyai peran strategis terhadap keberhasilan mencapai tujuan organisasi, baik pemerintah maupun swasta.

Pengembangan sumber daya manusia bertujuan menghasilkan kerangka kerja yang bertalian secara logis dan komprehensif untuk mengembangkan lingkungan dimana karyawan didorong belajar berkembang (Sedarmayanti, 2008:167). Pengembangan sumber daya manusia adalah upaya berkesinambungan meningkatkan mutu sumber daya manusia dalam arti yang seluas-luasnya, melalui pendidikan, latihan, dan pembinaan (Silalahi, 2000:249).

Pengembangan sumber daya manusia merupakan suatu cara efektif untuk menghadapi beberapa tantangan yang di hadapi oleh banyak organisasi besar. Tantangan-tantangan ini mencakup keusangan karyawan, perubahanperubahan sosioteknis dan perputaran tenaga kerja. Kemampuan untuk mengatasi tantangantantangan tersebut merupakan faktor penentu keberhasilan departemen personalia dalam mempertahankan sumber daya manusia yang efektif (Handoko, 2008:117).

Dalam hal ini, sesuai salah satu misi pembangunan Kabupaten Ciamis adalah meningkatkan kualitas sumber daya manusia dengan tujuan untuk meningkatkan pengembangan dan pelestarian seni dan budaya daerah serta sasarannya pengembangan dan penguatan nilai budaya yang berkembang di masyarakat. Adapun indikator kinerja dengan pendataan jumlah situs seni dan budaya; untuk situs pada tahun 2014 berjumlah 243, tahun 2015 berjumlah 283, tahun 2016 berjumlah 303 , tahun 2017 berjumlah 323, tahun 2018 berjumlah 343 (RJPMD Kab.Ciamis, 2014: 9). Berdasarkan data tersebut mengalami peningkatan dalam aspek keberadaan jumlah situs yang ada di Kabupaten Ciamis. Hanya saja, apakah di situssitus tersebut terdapat SDM yang memahami dari aspek pengetahuan, sikap dan keterampilan sesuai kebutuhan wisatawan. Kemampuan pada aspek pengetahuan, sikap dan keterampilan harus dimiliki bagi SDM yang berada di situs tersebut sehingga wisatawan yang berkunjung pada salah satu objek wisata budaya yang ada di Kabupaten Ciamis akan terpenuhi dari segi pengetahuan tentang keberadaan situs terkait sejarah dan budayanya, pelayanan dan kenyamanan, serta akses menuju situs tersebut dapat dengan mudah terjangkau. Hal inipun tentunya sama pada objek wisata budaya lainnya bahwa wisatawan yang berkunjung selayaknya mendapatkan pengetahuan, sikap, dan pelayanan yang terbaik msehingga wisatawan tersebut akan tetap kembali berkunjung ke objek wisata budaya yang ada di Kabupaten Ciamis. Peran SDM sangat menentukan bagi keberhasilan dalam pengembangan pariwisata budaya di Kabupaten Caimis. Maka dari itu, SDM yang berada di objek wisata budaya seharusnya mendapatkan pendidikan dan pelatihan pemandu wisata sesuai dengan kebutuhannya.

Pendidikan kepariwisataan merupakan salah satu kunci dalam mengembangkan potensi kepariwisataan (kawasan wisata), karena bidang ini memerlukan tenaga kerja terampil yang secara terus menerus harus dikembangkan. Menurut Spillane James. J (1994): "Salah satu masalah dalam mengembangkan pariwisata adalah tidak tersedianya fasilitas yang cukup untuk menunjang pendidikan pariwisata. Tenaga kerja yang cakap, terampil, memiliki skill tinggi dan pengabdian pada bidangnya (professional) menjadi kebutuhan mutlak dalam bersaing dipasaran global. Produk industri pariwisata adalah "jasa", oleh karena itu penekanannya harus pada segi pelayanan yang disesuaikan dengan kebutuhan wisatawan. Dalam industri pariwisata, kualitas pelayanan merupakan indikator utama yang menunjukkan tingkat professionalnya (Setiawan, 2016: 29-30).

Selain pendidikan pariwisata sebagai salah satu dalam meningkatkan peran SDM dalam pengembangan pariwisata budaya di Kabupaten Ciamis adalah melalui pelatihan. Pelatihan membantu seseorang memahami suatu pengetahuan praktis dan bertujuan untuk meningkatkan keterampilan, kecakapan, dan sikap yang diperlukan organisasi untuk mencapai tujuan (Ranupandojo, 1985:70). 
Dalam konteks mempersiapkan sumber daya manusia pendukung pariwisata di Kabupaten Ciamis, maka jenis pelatihan yang relevan untuk diimplementasikan yaitu: 1) Pelatihan Kepariwisataan; 2) Pelatihan Sadar Budaya Wisata; 3) Pelatihan Pemandu Wisata. Namun, dalam tulisan ini menitikberatkan pada pelatihan pemandu wisata sesuai dengan solusi atas permasalahan yang terkait dengan belum optimalnya kunjungan wisatawan ke objek wisata budaya di Kabupaten Ciamis, karena keterlibatan peran SDM sebagai salah satu kunci keberhasilan dalam pengembangan pariwisata budaya di Kabupaten Ciamis.

Pelatihan merupakan upaya untuk mengembangkan sumber daya manusia melalui peningkatan keterampilan sehingga mampu meningkatkan kompetensi individu maupun kelompok. Dalam pelaksanaan pelatihan lebih menekankan pada praktek secara langsung daripada teori. Adapun tujuan program pelatihan pada dasarnya untuk mengembangkan pengetahuan, keterampilan, dan sikap yang telah dimiliki oleh karyawan agar memiliki kompetensi yang sesuai dengan pekerjaanya atau sesuai dengan bidang yang ditekuni (Anwar, 2006: 166)

Pemandu wisata disebut juga pramuwisata atau tour guide. "Pemandu wisata adalah seseorang yang memberi penjelasan serta petunjuk kepada wisatawan dan treveller lainnya tentang segala sesuatu yang hendak dilihat dan disaksikan bilamana mereka berkunjung pada suatu objek, tempat atau daerah wisata tertentu" (Suwantoro, 1997: 13). Dalam kamus istilah pariwisata dan perhotelan, Soemarno dalam Muhajir (2005) memberikan definisi pramuwisata sebagai seseorang yang bertugas mengantar tamu ke objek wisata dan menerangkan objek wisata tersebut

$$
\text { Menurut Desky (2001: 29-30), }
$$

berdasarkan posisi pemandu wisata (guide) dalam perjalanan biro wisata maka dikenal tiga jenis guide yaitu guide freelance, guide semi staff, dan guide staff. Selanjutnya akan dijelaskan sebagai berikut: 1) Guide Freelance Adalah seorang guide lepas yang sama sekali tidak mempunyai ikatan dengan manajemen biro perjalanan wisata. Mereka bekerja untuk sebuah biro perjalanan wisata selama tenaganya dibutuhkan oleh biro perjalanan itu. Imbalan atau pendapatan yang diperoleh berdasarkan jam kerja mereka. 2) Guide Semi Staff Adalah seorang guide yang bekerja hanya pada satu biro perjalanan saja. Oleh karenanya biro perjalanan tersebut berkewajiban memberikan prioritas kepadanya untuk memandu wisatawan yang ada dalam biro perjalanan tersebut. Mereka tidak memperoleh gaji bulanan, tetapi tetap gaji imbalan sesuai dengan jam kerjanya. 3) Guide Staff Adalah guide yang memiliki status sebagai pegawai resmi sebuah biro perjalanan wisata. Mereka memperoleh gaji bulanan sebagaimana karyawan yang lain. Selama tidak ada tugas pemanduan, mereka harus ikut membantu pekerjaan lain yang ada dalam biro perjalanan tersebut.

Pemandu wisata merupakan pemimpin dalam suatu perjalanan wisata, secara umum tugas seorang pemandu wisata adalah sebagai berikut: 1) To conduct/to direct, yaitu mengatur dan melaksanakan kegiatan perjalanan wisata bagi wisatawan yang ditanganinya berdasarkan program perjalanan yang telah ditetapkan. 2) $T o$ point out, yaitu menunjukkan dan mengantarkan wisatawan ke objek-objek dan daya tarik wisata yang dikehendaki. 3) To inform, yaitu memberikan informasi dan penjelasan mengenai objek dan daya tarik wisata yang dikunjungi, informasi sejarah dan budaya, dan berbagai informasi lainnya (Irawati, 2013: 38).

Dalam pelaksanaan pelatihan pemandu wisata terdapat beberapa tahapan yang harus dilakukan sebagai berikut:

\section{Tahap Persiapan}

1) Sosialisasi program pelatihan pemandu wisata

Tujuan sosialisasi program ini adalah agar masyarakat mengetahui rencana kegiatan yang akan dilakukan mengenai program pelatihan pemandu wisata. Sesuai dengan kebutuhan perkembangan industri pariwisata yang begitu pesat sehingga pemandu wisata yang berkompeten dan professional harus terpenuhi. Hanya saja, sebelum melakukan sosialisasi tersebut penyelenggara harus menyusun program kegiatan pelatihan pemandu wisata. Selanjutnya, dapat melaksanakan sosialisasi pelatihan pemandu wisata kepada masyarakat atau siswa-siswa yang berminat sebagai pemandu wisata melalui penyebaran brosur, internet/media sosial, serta dapat berkunjung ke sekolah-sekolah yang ada di Kabupaten Ciamis. 2) Karakteristik Peserta

Peserta pelatihan pemandu wisata bagi masyarakat umum adalah laki-laki atau perempuan, pendidikan minimal SLTA/sederajat, memiliki KTP wilayah Kabupaten Ciamis, serta menguasai bahasa Indonesia dengan baik dan atau salah satu bahasa 
asing dengan aktif. Adapun peserta pelatihan pemandu wisata bagi kalangan pelajar adalah laki-laki atau perempuan, masih dalam pendidikan SLTA/sederajat serta menguasai bahasa Indonesia dengan baik dan atau salah satu bahasa asing dengan aktif.

\section{3) Seleksi Peserta}

Pelaksanaan seleksi pelatihan pemandu wisata dilakukan oleh tim penyelenggara yang telah dibentuk melalui: pendaftaran peserta pelatihan, tes kemampuan bahasa secara lisan, pengumuman peserta yang lolos mengikuti tes, daftar ulang peserta.

4) Mempersiapkan Kebutuhan Pelatihan

Kebutuhan pelatihan terkait dengan sarana dan prasarana yang dibutuhkan untuk menunjang kegiatan pelatihan diantaranya: tempat, modul, media pembelajaran, toolkits, narasumber, dan jadwal pembelajaran.

\section{Tahap Pelaksanaan}

1) Narasumber

Narasumber pada kegiatan pelatihan ini adalah tenaga pendidik yang memiliki kompetensi sesuai dengan bidangnya masingmasing yang diperlukan pada setiap materi yang disajikan dalam pelatihan.

2) Interaksi Narasumber dengan Peserta Pelatihan

Narasumber sebagai fasilitator dan bukan sebagai satu-satunya sumber informasi sehingga akan terjadi komunikasi dua arah antara narasumber dengan peserta.

3) Lokasi

Lokasi penyelenggaraan pelatihan harus sudah ditentukan sejak awal melalui observasi terlebih dahulu sesuai dengan kebutuhan.

4) Waktu Pelaksanaan

5) Materi Pelatihan

Penyusunan materi pelatihan pemandu wisata harus dipersiapkan karena dalam materi tersebut meliputi: deskripsi materi, alokasi waktu, alokasi waktu, sumber belajar serta evaluasi yang akan dilakukan.

\section{6) Metode}

Metode yang dilakukan dalam pelatihan meliputi: ceramah, tanya jawab, praktek.

7) Strategi Pembelajaran

Strategi pembelajaran berpusat pada narasumber namun terbuka antara peserta pelatihan dengan narasumber terjalin komunikasi dua arah sehingga terciptanya pembelajaran yang kondusif.

8) Sarana dan Prasarana

9) Sumber Biaya

\section{Tahap Evaluasi}

Evaluasi pelaksanaan pelatihan pemandu wisata dilakukan setelah proses pembelajaran selesai. Evaluasi dilaksanakan dengan tujuan mengukur sejauh mana penguasaan pengetahuan dan keterampilan yang telah dimiliki oleh peserta setelah selesai mengikuti kegiatan pelatihan. Evaluasi ini dilakukan dengan dua cara yaitu: uji materi dan uji praktek.

Dari hasil penelitian yang dilakukan maka yang menjadi output dari pelaksanaan pendidikan kepariwisataan dan pelatihan pemandu wisata yaitu: a) Peserta mampu memahami pengetahuan terkait pendidikan kepariwisataan dan kepemanduan. Peserta mampu memahami pendidikan kepariwisatan dan teknik-teknik menjadi seorang pemandu wisata. c) Peserta mampu memahami sikapsikap yang harus dimiliki sebagai pemandu wisata. d) Peserta mampu melakukan praktek sebagai pemandu wisata. Sedangkan Outcomes yang diperoleh dari program pendidikan pariwisata dan pelatihan pemandu wisata diharapkan peserta dapat mengaplikasikan ilmu dan keterampilan yang mereka dapatkan dalam pekerjaannya sebagai pemandu wisata yang berkompeten dan professional.

Berdasarkan hal tersebut di atas, peran sumber daya manusia sebagai faktor kunci keberhasilan dalam mewujudkan pengembangan pariwisata budaya di Kabupaten Ciamis. Peran SDM sebagai motor penggerak industri pariwisata, pencipta produk industri pariwisata, dan sebagai penentu daya saing industri pariwisata. Hal ini dapat diwujudkan melalui pendidikan pariwisata dan pelatihan pemandu wisata yang harus dimiliki bagi masyarakat khususnya berada di daerah wisata untuk mengembangkan pariwisata budaya di wilayah Kabupaten Ciamis, karena melalui kegiatan tersebut akan lebih meningkatkan mutu, kinerja dan hasil yang diperoleh menjadi lebih baik. Maka, peran SDM sangat menunjang keberhasilan bagi pengembangan pariwisata budaya di Kabupaten Ciamis dengan kompetensi yang dimilikinya, sehingga objek wisata budaya yang ada di Kabupaten Ciamis menjadi tujuan wisata yang lebih menarik dan memiliki keunikan yang kaya akan nilai sejarah dan budaya Galuh serta bermanfaat bagi masyarakat yang berada di daerah wisata sebagai sarana memperoleh penghasilan sehingga kesejahteraan masyarakatpun akan lebih meningkat. 


\section{PENUTUP}

\section{Simpulan}

Berdasarkan pembahasan di atas, dapat disimpulkan bahwa potensi yang dapat dikembangkan menjadi objek daya tarik wisata (ODTW) di wilayah Kabupaten Ciamis adalah berupa daya tarik wisata sejarah dan budaya. Sumber Daya Manusia adalah individu/pelaku industri pariwisata yang memiliki keterkaitan baik secara langsung maupun tidak langsung dengan komponen pariwisata. Sumber Daya Manusia memegang peranan penting dalam pengembangan pariwisata budaya di Kabupaten Ciamis sebagai kunci keberhasilan untuk meningkatkan kinerja lebih baik dan hasilnyapun menjadi lebih optimal. Strategi dalam pengembangan pariwisata budaya dapat dilakukan melalui pendidikan pariwisata dan pelatihan pemandu wisata kepada masyarakat.

Hasil dari kegiatan pendidikan pariwisata dan pelatihan pemandu wisata adalah Peserta mampu memahami pengetahuan terkait pendidikan kepariwisataan dan kepemanduan. Peserta mampu memahami pendidikan kepariwisatan dan teknik-teknik menjadi seorang pemandu wisata. Peserta mampu memahami sikap-sikap yang harus dimiliki sebagai pemandu wisata. Peserta mampu melakukan praktek sebagai pemandu wisata. Sedangkan Outcomes yang diperoleh dari program pendidikan pariwisata dan pelatihan pemandu wisata diharapkan peserta dapat mengaplikasikan ilmu dan keterampilan yang mereka dapatkan dalam pekerjaannya sebagai pemandu wisata yang berkompeten dan professional. Peran SDM sangat menunjang keberhasilan bagi pengembangan pariwisata budaya di Kabupaten Ciamis dengan kompetensi yang dimilikinya, sehingga objek wisata budaya yang ada di Kabupaten Ciamis menjadi tujuan wisata yang lebih menarik dan memiliki keunikan yang kaya akan nilai sejarah dan budaya Galuh serta bermanfaat bagi masyarakat yang berada di daerah wisata untuk meningkatkan kesejahteraannya.

Ada beberapa saran yang akan diusulkan penulis berdasarkan hasil analisis tersebut yaitu: 1. Pengembangan sumber daya manusia sebagai pelaku kebijakan dalam bidang kepariwisataan melalui jenjang pendidikan yang bersifat formal maupun non formal.

2. Menjalin kemitraan dengan lembaga pendanaan (bank maupun non-bank) baik lembaga pemerintah maupun swasta untuk menciptakan investasi baru dalam rangka mengembangkan daerah tujuan wisata.

3. Melaksanakan koordinasi secara terpadu antar semua pihak yang terkait sehingga terwujud keterpaduan lintas sektoral dan menghindari terjadinya konflik antar sektor.

4. Melaksanakan program-program promosi yang efektif secara berkesinambungan, untuk meningkatkan jumlah kunjungan wisata baik wisatawan manca Negara maupun wisatawan nusantara.

5. Melaksanakan pembinaan mengenai kesadaran dan peran aktif masyarakat untuk menjaga, melindungi, dan melestarikan aset kebudayaan yang ada.

\section{DAFTAR PUSTAKA}

Anwar. 2006. "Pendidikan Kecakapan Hidup (life skills education) Konsep dan Aplikasi". Bandung: Alfabeta.

Desky, MA. 2001. "Manajemen Perjalanan Wisata". Yogyakarta: Adicita Karya Nusa.

Dinas Pariwisata dan Ekonomi Kreatif Kabupaten Ciamis. 2016. "Pariwisata dan Ekonomi Kreatif Kabupaten Ciamis 2016". Ciamis: Dinas Pariwisata dan Ekonomi Kreatif Kabupaten Ciamis.

Ethika, Takariadinda Diana. 2016. Pengembangan Pariwisata Berbasis Budaya Berdasarkan Undang-Undang No. 10 Tahun 2009 Di Kabupaten Sleman. Jurnal Kajian Hukum Vol.1 No. 2 tahun 2016.

Evans, Nigel, David Campbell \& George Stonehouse. 2003. "Strategic Management for Travel and Tourism". Oxford: Butterworth-Heinemann.

Handoko, Hani. 1999. "Perilaku Organisasi". Yogyakarta: BPFE UGM.

Irawati, Linda. 2013. "Pelaksanaan Pendidikan Dan Pelatihan (Diklat) Pemandu Wisata Untuk Meningkatkan Kompetensi Pemandu Wisata Di Dewan Pimpinan Daerah Himpunan Pramuwisata Indonesia (DPD HPI) Yogyakarta". Skripsi. Yogyakarta: Universitas NegeriYogyakarta.

Iskandar, Yoseph. 2001. "Sejarah Jawa Barat". Bandung: Geger Sunten.

Khotimah, Wilopo. Luchman Hakim. 2017. "Strategi Pengembangan Destinasi 
Pariwisata Budaya". Jurnal Administrasi Bisnis. Vol. 41 No. 1 Januari 2017.

Krisdianto, Bayu \& Nurhajati. 2017. "Pengaruh Pengembangan Sumber Daya Manusia dan Motivasi Terhadap Kinerja Pegawai Dinas Pariwisata Kota Batu". Jurnal JIMMU. Vol. II No. 2 Agustus 2017.

Larasati, Ni Ketut Ratih \& Dian Rahmawati. 2017. Strategi Pengembangan Pariwisata Yang Berkelanjutan Pada Kampung Lawas Maspati Surabaya. Jurnal Teknik ITS Vol. 6 No. 2 Tahun 2017.

Pemerintah Daerah Kabupaten Ciamis. 2008. "Rencana Pembangunan Jangka Panjang Daerah (RPJPD) Kabupaten Ciamis Tahun 2005-2025". Laporan Naskah Akademik. Pemerintah Kabupaten Ciamis. Pemerintah Daerah Kabupaten Ciamis. 2014. "Rencana Pembangunan Jangka Menengah Daerah (RPJMD) Tahun 20142019". Peraturan Daerah Kabupaten Ciamis No. 13 Tahun 2014. Pemerintah Kabupaten Ciamis.

Pemerintah Daerah Kabupaten Ciamis. 2015. "Laporan Kinerja Pertanggungjawaban Bupati”. Pemerintah Daerah Kabupaten Ciamis.

Muallidin, Isnaini. 2007. "Model Pengembangan Pariwisata Berbasis Masyarakat Di Kota Yogjakarta". Jurnal PENELITIAN. No. 2. Desember 2007.

Muhajir. 2005. "Menjadi Pemandu Wisata Pemula". Jakarta : PT Gramedia Widiasarana Indonesia.

Nandi. 2008. "Pariwisata dan Pengembangan Sumber Daya Manusia". Jurnal GEA Jurusan Pendidikan Geografi. Vol. 8 No. 1 April 2008.

Ranupandojo, Heidjrachman. 1985. "Manajemen Personalia". Yogyakarta: BPFE.

Rivai, H. Veithzal dan Sagala, Ella Jauvani. 2009. "Manajemen Sumber Daya Manusia Untuk Perusahaan Edisi 2". Jakarta: PT. Raja Grafindo.

Sedarmayanti. 2008. "Manajemen sumber Daya Manusia". Jakarta: Grasindo.

Setiawan, Rony Ika. 2016. "Pengembangan Sumber Daya Manusia di Bidang Pariwisata": Perspektif Potensi Wisata Daerah Berkembang. Jurnal PENATARAN. Vol. 1 No.1
Silalahi, Berneth. 2000. "Manajemen Sumberdaya Manusia". Jakarta: Sekolah Tinggi Ilmu Manajemen LPMI.

Suwantoro, Gamal. 1997. "Dasar-Dasar Pariwisata". Yogyakarta: Andi.

Spillane, James J. 1987. "Pariwisata Indonesia: Sejarah dan Prospeknya". Yogyakarta: Kanisius.

Undang-Undang Nomor 10 tahun 2009 tentang Kepariwisataan.

Wasino. 2016. "Nasionalisme PerusahaanPerusahaan Asing Menuju Ekonomi Berdikari”. Jurnal Paramita. Vol. 26 No. 1- Tahun 2016. 